\title{
Other Uses of the Name of Umbilicus
}

The word 'navel', or its equivalent in other languages, has been used sometimes for the centre for something, e.g. 'nave' for the hub of a wheel. Tortellini might represent the belly button of Venus.

In recent years the cell phone was called the world's longest umbilical cord. The term 'umbilical cord' or just 'umbilical' has also come to be used for other cords with similar functions, such as the hose connecting a surface-supplied diver to his surface supply of air and/or heating or a space-suited astronaut to his spacecraft.

The phrase 'cutting the umbilical cord' is used symbolically to describe a child's breaking away from the parental home.
In Siberian the midwife is called 'navel mother' and the child 'navel son' or 'navel daughter'.

Alexandria city itself is called as 'the umbilicus of the ancient world'.

The Umbilicus Urbis in Rome was a special monument in the Forum Romanum, indicating the symbolic centre of the city: the 'Navel of the City of Rome'. The remains of the monument are located beside the Arch of Septimius Severus, behind the Rostra and near the Temple of Concord and the Temple of Saturn. 